\title{
Monitoring of PV Performance Using LabVIEW
}

\author{
Siti Amely Jumaat, Ammar Syahmi Bin Mohd Anuar, Mohd Noor Abdullah, Nur Hanis Radzi, \\ Rohaiza Hamdan, Suriana Salimin, Muhammad Nafis bin Ismail \\ Green and Sustainable Energy Focus Group, Faculty of Electrical and Electronic Engineering, \\ Universiti Tun Hussein Onn Malaysia (UTHM), 86400, Parit Raja Batu Pahat, Johor, Malaysia
}

\begin{tabular}{l}
\hline Article Info \\
\hline Article history: \\
Received May 9, 2018 \\
Revised Jun 20, 2018 \\
Accepted Jul 11, 2018 \\
\hline
\end{tabular}

Keywords:

Arduino

LabVIEW

PV

Solar

\begin{abstract}
This project aims to design a simulator for PV monitoring using LabVIEW. This project will be divided into two parts; software where LabVIEW and Arduino IDE been contracted and hardware parts. First part involves the software development. In this project, LabVIEW program is used as the main program to monitor the output of solar panel; voltage, current, power and temperature in real time. Next, the Arduino IDE program is used to interact the sensors with the Arduino board. The Arduino Uno microcontroller board is used as data acquisition medium to collect data from the solar panel. Second, the hardware part which is PV panel setup and measurement circuit that consist of sensors and Arduino board so that the sensors data will transfer and display to the PC connected. In this simulator, the sensors are connected to the Analog I/O of Arduino Uno microcontroller which read the analogue input of sensors. The Arduino then is connected to the PC program LabVIEW to display the I-V graph and P-V graph. To make the data more significant, the data will be collected at the location $1.8635^{\circ} \mathrm{N}, 103.1089^{\circ} \mathrm{E}$ which is in Parit Raja, Batu Pahat, Johor. The data was collected with 3 different day and time; 12PM, 1PM and 2PM on 28/11/2017, 29/11/2017 and $30 / 11 / 2017$.
\end{abstract}

Copyright @ 2018 Institute of Advanced Engineering and Science. All rights reserved.

\section{Corresponding Author:}

Siti Amely Jumaat,

Green and Sustainable Energy Focus Group, Faculty of Electrical and Electronic Engineering,

Universiti Tun Hussein Onn Malaysia (UTHM),

86400, Parit Raja Batu Pahat, Johor, Malaysia.

Email: amely@uthm.edu.my

\section{INTRODUCTION}

Photovoltaic is a conversion of light energy into electrical energy and this process is known as photoelectric effect. This effect causes photovoltaic to absorbs photons and release electrons on the material. This emitted electron is measured as an electric current. There are many types photovoltaic cells such as monocrystalline silicon, polycrystalline silicon, thin film, cadmium telluride and many more. In Malaysia, there are only four types are available which are monocrystalline silicon, polycrystalline silicon, copperindium diselinide and thin film. According to Energy Commission based on performance and statistical information on electricity supply industry in Malaysia 2014, Malaysia's electricity generation totalled at 30,875.23 MW including solar/photovoltaic system which contribute 0.55\% [1]. However, based on Sustainable Energy Development Authority Malaysia (SEDA), solar generation is increasing by year since 2012 [2]. These data showed potential that photovoltaic or solar energy generation can be one of the main energy generation in Malaysia. The purposes of this research are to design and simulate a simulator for photovoltaic array monitoring, to monitor a photovoltaic array efficiency system based on I-V and P-V curve and to obtain early warning of faults that may cause by weather damage, shading, defect and improper installation. 
Some research has been made to make a proper design of the simulator. In this paper [3], it presents a detailed characterization of the performance and dynamic behaviour of photovoltaic system by using LabVIEW which is a real-time interface system. In paper [4], a diagnosis of PV arrays which to detect and localize the fault in photovoltaic generator when a limited numbers of voltage sensors are used. Next, this paper [5] discussed the performance of solar PV is evaluated based on the model implemented using Matlab/Simulink. The model consists of battery storage, controller and converters. This last paper [6] discussed about monitoring a solar array using LabVIEW GUI and several smart sensors that communicate through a wireless sensor network. The collected data and analytics are then processed to form an I-V and P$\mathrm{V}$ curve that can be obtained using an internet that connected through smartphone, tablet and also PC.

\section{SPECIFICATION OF COMPONENTS AND SOFTWARE}

This part discusses the main components that used on this research.

\subsection{Solar Cell}

In this research, this solar module is made of polycrystalline silicon and protected by a durable outer poly frame as shown in Figure 1. Table 1 are tabulated the specification of solar module [12]-[13].

Table 1. Specification of Solar Module

\begin{tabular}{|c|c|}
\hline Name & Specification \\
\hline Solar type & $\begin{array}{l}\text { Polycrystalline } \\
\text { silicon }\end{array}$ \\
\hline $\begin{array}{l}\text { Maximum } \\
\text { voltage }\end{array}$ & 9Volt \\
\hline $\begin{array}{l}\text { Maximum } \\
\text { current }\end{array}$ & $350 \mathrm{~mA}$ \\
\hline Power & 3Watt \\
\hline Dimension & $\begin{array}{c}125 \mathrm{~mm} \times \\
195 \mathrm{~mm} \times 3 \\
\mathrm{~mm}\end{array}$ \\
\hline
\end{tabular}

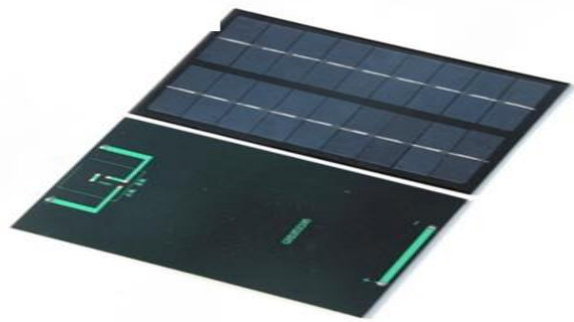

Figure 1. The Solar PV Polycrystalline Type (GH125X195)

\subsection{Arduino Board}

An Arduino UNO is a microcontroller board based on ATmega328P. It has 14 digital I/O pin, 6 analogue inputs, a USB connection, a $16 \mathrm{MHz}$ quartz crystal, a reset button and a power jack as shown in Figure 2. Arduino also consist of both physical programmable board and software IDE that is to use to write and upload the code [7].

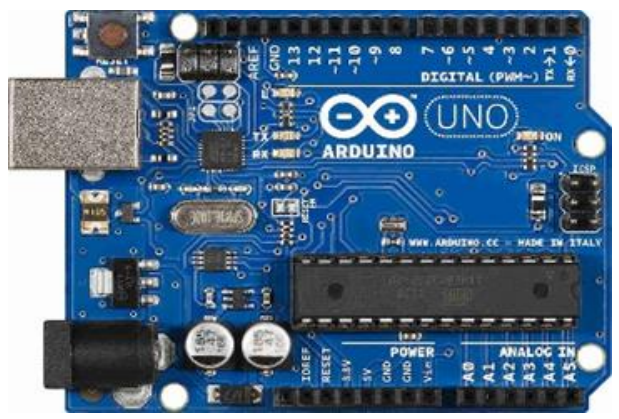

Figure 2. The Arduino Board

\subsection{Current Sensor (ACS 712)}

The ACS 712 are designed to be easily used with microcontrollers like Arduino as shown in Figure 3. This sensor is based on the Allegro ACS712ELC chip. The sensor can measure positive and negative current and the supply is $5 \mathrm{~V}$ for the sensor. This sensor also gives precise measurement for $\mathrm{AC}$ and DC signals. Table 2 are tabulated the specification of current sensor [8]. 
Table 2. Specification of Current Sensor

\begin{tabular}{cc}
\hline Name & Specification \\
\hline Supply voltage; 5V & $5 \mathrm{Vdc}$ \\
Measurement Range & -5 to $+5 \mathrm{Amps}$ \\
Scale factor & $185 \mathrm{mV}$ per Amp \\
Chip & ACS712ELC-05A \\
Voltage at 0A & Vcc/2 \\
\hline
\end{tabular}

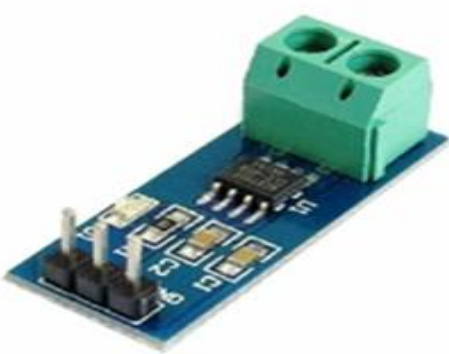

Figure 3. Current sensor

\subsection{Temperature Sensor (LM35)}

Temperature sensor is a device which measure temperature as shown in Figure 4. LM35 is a precision IC temperature sensor with its proportional to the temperature in Celsius. The operating temperature range is from -55 degree Celsius to 150 degrees Celsius. The output voltage is proportional to the temperature. The LM35 linear temperature sensor and sensor-specific expansion of Arduino board, in combination it can be very easy to achieve [9].

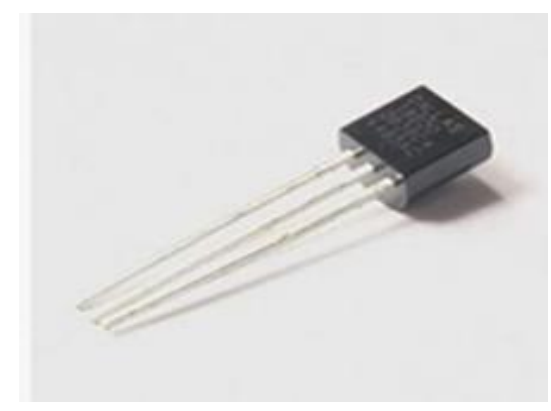

Figure 4. Temperature sensor

\subsection{LabVIEW}

The LabVIEW is an integrated development environment designed specifically for engineers and scientist. It also provides a graphical programming language named ' $G$ ' that uses a data flow model instead of code as shown in Figure 5. This software commonly used for data acquisition on a variety operating system. The source code of the software is determined by a graphical block diagram [10].

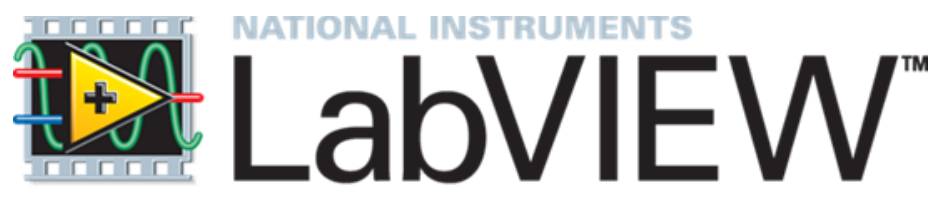

Figure 5. LabVIEW 


\section{PROJECT'S DEVELOPMENT}

This section is adopting methods approach involving some developments to enhance the simulator of PV monitoring. Which, it is discuss about the methodology of project. 3.1 Methodology of Project

A solar PV (GH125X195) is used. The between solar panels will be connected to voltage divider and act as voltage sensors. A current sensors (ACS712) is used in series with the solar PV panels. These current sensors communicate with measurement circuit and send the analogue input to the Arduino.The temperature sensor LM35 is an analogue read sensor which connected to analogue port of Arduino board. The ACS712 send data in a form of raw value of voltage. The voltage sense will be converted into current value in the LabVIEW program. From the datasheet, it stated that this temperature sensor has a precision of $350 \mathrm{~mA}$. To complete the setup, a variable load is connected to plot I-V and P-V characteristic. As shown in Figure 6.

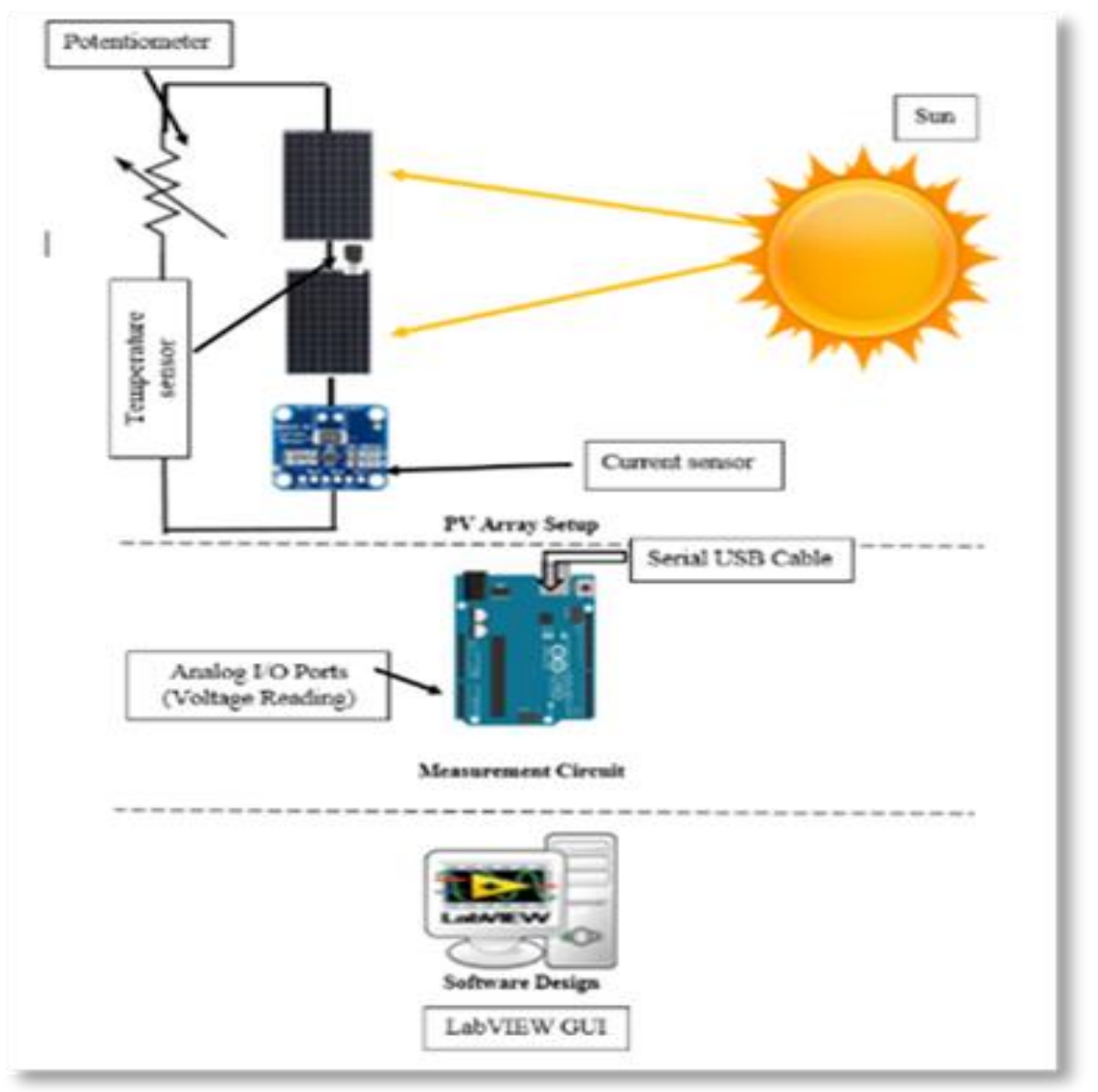

Figure 6. Block Diagram of LabVIEW Program

\section{RESULTS AND ANALYSIS}

This section discusses about the I-V and P-V graph that recorded from the LabVIEW. The data was collected with 3 different day and time; 12PM, 1PM and 2PM on 28/11/2017, 29/11/2017 and 30/11/2017.

\subsection{LabVIEW's Block Diagram}

The LabVIEW's program consists of block diagram and the front panel. The front panel is for the user and being used as indicator and control. The block diagrams are created to supply information to the Virtual Instrument while the indicator are output to indicate and display the result based on the inputs given. A LINX LabVIEW tools is used to remotely control the input and interacting with common embedded platforms like Arduino. The built sensors are used to get the data to PC in seconds. The Figure 7 shows the block diagram of LabVIEW Program [11]. 


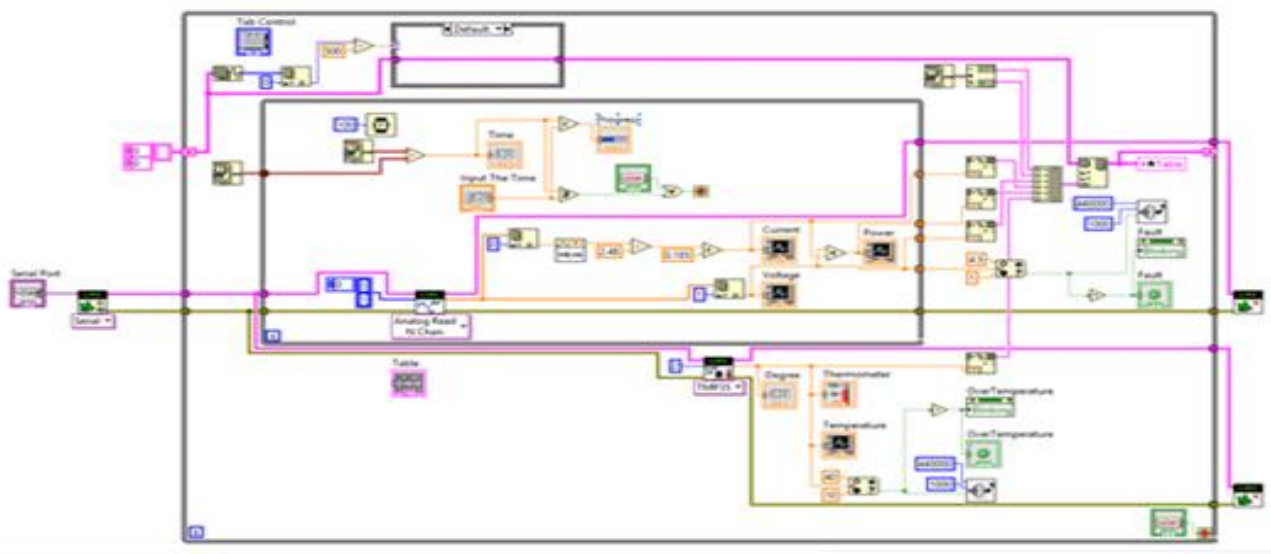

Figure 7. Block Diagram of LabVIEW Program.

\subsection{Prototype of Project}

Figure 8 shows the hardware setup of the project which consist of multiple sensors and Arduino board as data acquisition.

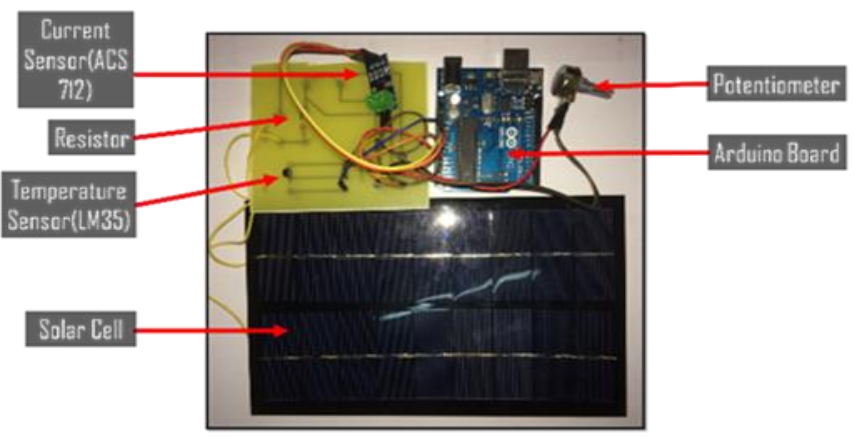

Figure 8. Hardware Setup

\subsection{I-V and P-V Graph}

Table 3 and Table 4 shows the data of voltage and current collected from three days starting from $28 / 11 / 2017$ until 30/11/2017. The data was recorded three times a day which is at $12 \mathrm{pm}, 1 \mathrm{pm}$ and $2 \mathrm{pm}$. The mean daily sunshine hours in Malaysia ranges between 4 to 8 hours per day. At $12 \mathrm{pm}$ to $2 \mathrm{pm}$ are the peak sun hours which give a good solar production.

From the 3 days' data at $12 \mathrm{pm}$, the minimum range voltage is $1.13 \mathrm{~V}$ and maximum voltage is $4.49 \mathrm{~V}$. The 3 days' data at $1 \mathrm{pm}$; the minimum range voltage is $1.27 \mathrm{~V}$ and maximum voltage is $3.64 \mathrm{~V}$. From the 3 days' data at $2 \mathrm{pm}$; the minimum range voltage is $0.95 \mathrm{~V}$ and maximum voltage is $4.04 \mathrm{~V}$.

Table 3. Voltage Data Collected

\begin{tabular}{llll}
\hline Time/Date & $\mathbf{2 8 / 1 1 / 2 0 1 7}$ & $\mathbf{2 9 / 1 1 / 2 0 1 7}$ & $\mathbf{3 0 / 1 1 / 2 0 1 7}$ \\
\hline 12 PM & $0.63 \mathrm{~V}-4.74 \mathrm{~V}$ & $1.76 \mathrm{~V}-3.92 \mathrm{~V}$ & $1.01 \mathrm{~V}-4.82 \mathrm{~V}$ \\
$\mathbf{1 ~ P M}$ & $1.95 \mathrm{~V}-4.21 \mathrm{~V}$ & $1.40 \mathrm{~V}-3.96 \mathrm{~V}$ & $0.46 \mathrm{~V}-2.76 \mathrm{~V}$ \\
$\mathbf{2} \mathbf{P M}$ & $0.63 \mathrm{~V}-4.21 \mathrm{~V}$ & $1.07 \mathrm{~V}-4.12 \mathrm{~V}$ & $1.17 \mathrm{~V}-3.80 \mathrm{~V}$ \\
\hline
\end{tabular}

From the 3 days' data at $12 \mathrm{pm}$, the minimum range current is $0.083 \mathrm{~A}$ and maximum current is $0.113 \mathrm{~A}$. The data collected for the 3 days' data at $1 \mathrm{pm}$; the minimum range current is $0.056 \mathrm{~A}$ and maximum current is $0.063 \mathrm{~A}$. For the 3 days' data at $2 \mathrm{pm}$; the minimum range current is $0.11 \mathrm{~A}$ and maximum current is $0.18 \mathrm{~A}$. 


\begin{tabular}{llll}
\hline Time/Date & $\mathbf{2 8 / 1 1 / 2 0 1 7}$ & $\mathbf{2 9 / 1 1 / 2 0 1 7}$ & $\mathbf{3 0 / 1 1 / 2 0 1 7}$ \\
\hline 12 PM & $0.02 \mathrm{~A}-0.05 \mathrm{~A}$ & $0.05 \mathrm{~A}-0.08 \mathrm{~A}$ & $0.18 \mathrm{~A}-0.21 \mathrm{~A}$ \\
1 PM & $0.05 \mathrm{~A}-0.03 \mathrm{~A}$ & $0.06 \mathrm{~A}-0.08 \mathrm{~A}$ & $0.06 \mathrm{~A}-0.08 \mathrm{~A}$ \\
2 PM & $0.24 \mathrm{~A}-0.31 \mathrm{~A}$ & $0.01 \mathrm{~A}-0.04 \mathrm{~A}$ & $0.08 \mathrm{~A}-0.19 \mathrm{~A}$ \\
\hline
\end{tabular}

\subsection{I-V and P-V Graph Characteristic Comparison}

The Figure 9 and Figure 10 shows the characteristic comparison with theoretical graph. The highest reading from the 3 readings were plotted and compared with the theoretical graph.

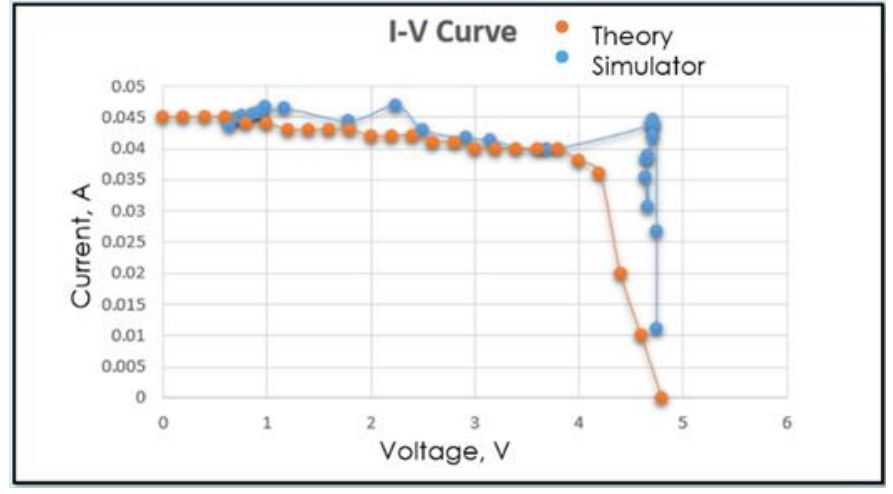

Figure 9. P-V Graph

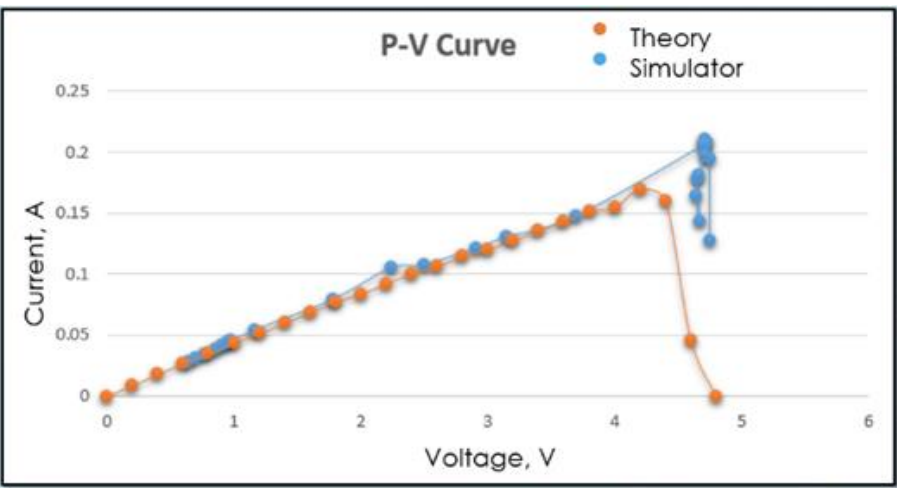

Figure 10. I-V Graph

\section{CONCLUSIONS}

In summary, a design of simulator for monitoring solar PV has been created. The system implemented with an Arduino board as data acquisition and LabVIEW software to analyse, record and display data from the sensors. From the front panel of the LabVIEW GUI, it indicates the value of voltage, current, power and also the temperature of the measurement device. Besides, all the data collected from the I$\mathrm{V}$ graph and P-V graph curve are analysed to monitor the solar PV efficiency. The data are recorded within 3 days with 3 different times which is $12 \mathrm{pm}, 1 \mathrm{pm}$ and $2 \mathrm{pm}$. Minimum and maximum value of voltage and current are analysed through this project. Furthermore, an alarm system has been created to obtain the early warning of faults. The system will detect the over temperature and the over voltage from the solar PV cell. This system was designed on the LabVIEW block diagram and display at the front panel of the GUI. According to the problem statement, it is very hard to recognised any faulty condition of the solar PV. By implementing this project, the difficulty to recognised the fault can be achieved. 


\section{ACKNOWLEDGEMENTS}

The authors would like to acknowledge the Research Management Center (RMC), Universiti Tun Hussein Onn Malysia (UTHM), Batu Pahat, Johor, Malaysia for the financial support of this search. This research is partly by RMC under the U861 (Tier 1) Grant.

\section{REFERENCES}

[1] Suruhanjaya Tenaga, ST-Performance and Statistical Information 2014. Suruhanjaya Tenaga, 2015.

[2] Sustainable Energy Development Authority Malaysia, "Annual Power Generation (MWh) of Commissioned RE Installations (2012 - 2016).” [Online]. Available: http://www.seda.gov.my/. [Accessed: 19-Feb-2017].

[3] A. Chouder, S. Silvestre, B. Taghezouit, and E. Karatepe, "Monitoring, modelling and simulation of PV systems using LabVIEW," Sol. ENERGY, 2012.

[4] R. Khenfer, M. Mostefai, S. Benahdouga, and M. Maddad, "Faults detection in a photovoltaic generator by using matlab simulink and the chipKIT Max32 board," Int. J. Photoenergy, vol. 2014, 2014.

[5] E M Natsheh and A Albarbar, "Solar power plant performance evaluation: simulation and experimental validation," vol. 12122, 2012.

[6] S. Penshin, "A Simulator for Solar Array Monitoring," Arizona State University, 2016.

[7] ATmel, “ATmega48A/PA/88A/PA/168A/PA/328/P [Material Safety Data Sheet]," 2015.

[8] Allegro, “ACS712 Datasheet,” pp. 1-14, 2007.

[9] L. Self-heating and L. I. Output, "LM35 Precision Centigrade Temperature Sensors," no. November, pp. 1-13, 2013.

[10] National Instrument, "LabVIEW System Design Software - National Instruments." [Online]. Available: http://www.ni.com/labview/. [Accessed: 14-May-2017].

[11] M. Schwartz, Programming Arduino with LabVIEW. 2015.

[12] SA Jumaat, F Mohamad, SA Zulkifli, Development of Portable Case Solar Battery Charger, Electrical and Electronic Engineering, Vol. 6 No. 4, 2016, pp. 55-61. doi: 10.5923/j.eee.20160604.01.

[13] Siti Amely Jumaat, Mohammad Hilmi Othman, Solar Energy Measurement Using Arduino, MATEC Web Conf. 150, 2018, 01007, p. 6 